\title{
Dairy productivity of the Swiss breed procensor of different genotypes in Uzbekistan
}

\author{
$M$ Ashirov $^{1, *}, U$ Soatov $^{2}, B$ Ashirov $^{3}$, and $K H$ Donaev $^{2}$ \\ ${ }^{1}$ Scientific Research Institute of Livestock and Poultry, Kizil Shalola village, Tashkent province, \\ Uzbekistan \\ ${ }^{2}$ Tashkent State Agrarian University, University str., 2, Tashkent province, 100140 Uzbekistan \\ ${ }^{3}$ Ministry of Agriculture of the Republic of Uzbekistan, University str., 2, Tashkent province, 100140 \\ Uzbekistan
}

\begin{abstract}
Studies have shown that the breeding cattle of the Swiss breed of different genotypes used in the selection in Uzbekistan are characterized by high breeding value. The cows obtained from them are distinguished by high milk productivity and fat-milk content, a high milk production coefficient, indicating a pronounced milk type. Cattle of Austrian breeding are characterized by a higher productivity potential. In some cattle cows, the milk yield by $191.3-417.1 \mathrm{~kg}$, the milk yield of $4 \%$ milk by $212.6-$ $472.6 \mathrm{~kg}$, the milk yield coefficient by $26.1-45.8 \mathrm{~kg}$ exceeds the corresponding indicators of the cows of other cattle. The calves of the cattle nick-named Karan, Koster, Emil and Jordan had milk yield at $1,174.8,1,219.4 ; 935.0$ and $1,010.4 \mathrm{~kg}$ respectively; milk fat yield by 52.9 ; $55.3 ; 45.3$, and $49.9 \mathrm{~kg}$ are higher than the requirements of the republican standard of the Swiss breed. Studies have confirmed that the use of semen from cattle -producers of the Swiss breed in breeding herds, regardless of origin, has a positive effect on the improvement of the main selection characteristics of cows of the Swiss breed of Uzbekistan.
\end{abstract}

\section{Introduction}

With the qualitative improvement of the breeding characteristics of livestock and the creation of highly productive dairy herds, the genotype of cow parents is of particular importance $[1,3,6]$. Successful selection of parental pairs with a high genetic potential for productivity is the key to obtaining highly productive offspring and creating highly productive dairy herds. The use of improver cattle evaluated by the quality of the offspring in the selection helps to accelerate the rate of qualitative improvement of breeds $[2,5,7]$.

The Swiss breed of Swiss cattle is one of the leading combination breeds in the world $[4,5]$. Due to the high milk productivity, especially the milk yield, lability, longevity and other valuable qualities of cows, the breed of cattle is widespread in 74 countries of the world on 5 continents of the globe [8- 10]. This breed is a planned breed for breeding in Uzbekistan $[11,12]$. In this regard, we studied the influence of the fathers' genotype on the level of milk production of the offspring.

\footnotetext{
*Corresponding author: m.i.ashirov@yandex.com
} 


\section{Materials and methods}

Investigations to study the milk productivity of cows obtained from cattle -producers of the Swiss breed of different genotypes were carried out in breeding herds of farms of the Andijan and Kashkadarya provinces of Uzbekistan. The conditions for feeding and keeping cows of different genotypes were the same. The milk productivity of cows has been studied for 305 days of lactation using methods generally accepted in zootechnics.

\section{Results and discussion}

Table 1 shows the productivity of first-calf heifers, calves of sire cattle of different genotypes in the breeding herd of the Avaz farm, Kurgantepa district, Andijan province.

Table 1. Dairy productivity and living mass of herds and calves of different breeding cattle.

\begin{tabular}{|c|c|c|c|c|}
\hline \multirow{2}{*}{ Index } & \multicolumn{4}{|c|}{ Nick-name of the sire cattle } \\
\cline { 2 - 5 } & Jury & Desirester & Emperor & Yudo \\
\hline Number of heads & 12 & 11 & 10 & 10 \\
\hline Milk yield, kg & $4,153.8 \pm 20.6$ & $4,103.3 \pm 122.5$ & $4,166.5 \pm 99.7$ & $4,088.9 \pm 157.8$ \\
\hline Fat content in milk,\% & $4.15 \pm 0.03$ & $4.13 \pm 0.03$ & $4.11 \pm 0.02$ & $4.14 \pm 0.03$ \\
\hline Milk fat yield, kg & $172.4 \pm 10.8$ & $169.5 \pm 7.2$ & $171.2 \pm 4.8$ & $169.3 \pm 5.7$ \\
\hline Milk yield of 4\% milk, kg & $4,309.6 \pm 187.4$ & $4,236.6 \pm 97.3$ & $4,281.1 \pm 103.2$ & $4,132.0 \pm 110.4$ \\
\hline $\begin{array}{c}\text { Output for every 100 kg of } \\
\text { biomass of milk, kg }\end{array}$ & $932.8 \pm 6.4$ & $934.3 \pm 5.9$ & $956.0 \pm 5.5$ & $948.7 \pm 7.2$ \\
\hline Biomass, kg & $445.3 \pm 4.9$ & $439.2 \pm 5.0$ & $435.8 \pm 3.7$ & $431.0 \pm 6.1$ \\
\hline
\end{tabular}

As the data in Table 1 show, all breeding cattle used in the breeding herd had an approximately equal and improving effect on the level of productivity of calves. In the calves of the Emperor's cattle, the milk yield per lactation I was unreliable by $12.7-77.6 \mathrm{~kg}$ higher, the milk yield per $100 \mathrm{~kg}$ of biomass was $7.3-23.2 \mathrm{~kg}(\mathrm{P}>0.99)$ more than in calves appertain to other cattle. We furthermore studied the productive qualities of the same cows for III and older lactation (Table 2).

Table 2. Productive indicators of calves of different cattle -producers for III and over lactation.

\begin{tabular}{|c|c|c|c|c|}
\hline \multirow{2}{*}{ Index } & \multicolumn{4}{|c|}{ Nick-name of the sire cattle } \\
\cline { 2 - 5 } & Jury & Desirester & Emperor & Yudo \\
\hline Number of heads & 12 & 11 & 10 & 10 \\
\hline Milk yield, kg & $5,464.8 \pm 334.9$ & $5,128.3 \pm 167.5$ & $5,273.5 \pm 198.4$ & $\begin{array}{c}5,047.7 \pm 1 \\
91.6\end{array}$ \\
\hline Fat content in milk,\% & $4.17 \pm 0.01$ & $4.15 \pm 0.03$ & $4.16 \pm 0.02$ & $4.14 \pm 0.03$ \\
\hline Milk fat yield, kg & $227.9 \pm 14.1$ & $212.3 \pm 8.4$ & $219.4 \pm 7.5$ & $209.0 \pm 5.7$ \\
\hline Milk yield of 4\% milk, kg & $5,697.0 \pm 109.2$ & $5,320.6 \pm 129.7$ & $5,484.4 \pm 120.5$ & $\begin{array}{c}5,224.4 \pm 1 \\
39.1\end{array}$ \\
\hline Milk ratio, kg & $1037.9 \pm 24.8$ & $994.2 \pm 21.2$ & $1,011.8 \pm 20.7$ & $\begin{array}{c}992.1 \pm 16 . \\
8\end{array}$ \\
\hline Biomass, kg & $526.5 \pm 7.94$ & $515.8 \pm 7.0$ & $521.2 \pm 6.1$ & $508.8 \pm 8.7$ \\
\hline
\end{tabular}

In these studies, full-age cows, regardless of the genotype of the fathers, are characterized by high milk production. The calves of the breeding cattle Zhuri have milk yield of $191.3-417.1 \mathrm{~kg}$, milk yield of $4 \%$ milk by $212.6-472.6 \mathrm{~kg}$, milk production coefficient by $26.1-45.8 \mathrm{~kg}$ exceeds the corresponding indicators of calves of other cattle. The calves of all breeding cattle are of the milk type, as evidenced by the milk production ratio. Studies in this aspect were continued in the breeding herd "Savai-naslchilik chorvachilik" of the Kurgantepa district of the Andijan province (Table 3). 
Table 3. Productive indicators of calves of different cattle for the I lactation.

\begin{tabular}{|c|c|c|c|c|}
\hline \multirow{2}{*}{ Index } & \multicolumn{4}{|c|}{ Nick-name of the sire cattle } \\
\cline { 2 - 5 } & Karan & Koster & Emil & Jordan \\
\hline Number of heads & 21 & 40 & 67 & 15 \\
\hline Milk yield, kg & $3,477.6 \pm 131.4$ & $3,491.5 \pm 128.6$ & $3,350.0 \pm 85.7$ & $3,403.4 \pm 59.5$ \\
\hline Fat content in milk, \% & $3.91 \pm 0.02$ & $3.90 \pm 0.03$ & $3.92 \pm 0.03$ & $3.96 \pm 0.02$ \\
\hline Milk fat yield, kg & $136.0 \pm 5.3$ & $136.2 \pm 6.0$ & $131.3 \pm 4.2$ & $134.8 \pm 4.8$ \\
\hline Milk yield of 4\% milk, kg & $3,399.5 \pm 107.8$ & $3,404.2 \pm 108.9$ & $3,283.0 \pm 90.0$ & $3,369.4 \pm 61.2$ \\
\hline $\begin{array}{c}\text { Milk yield per 100 kg of } \\
\text { biomass, } \mathrm{kg}\end{array}$ & $802.8 \pm 8.8$ & $780.8 \pm 7.5$ & $778.0 \pm 6.8$ & $787.6 \pm 5.0$ \\
\hline Biomass, $\mathrm{kg}$ & $433.2 \pm 4.4$ & $436.0 \pm 5.9$ & $430.6 \pm 4.1$ & $432.1 \pm 5.2$ \\
\hline
\end{tabular}

As can be seen from the data in Table 3, during the 1st lactation, the calves of cattle are characterized by an insignificant intergroup difference and the difference in productive indicators was not significant. However, it should be noted that the milk yield of first-calf heifers, calves of these cattle exceeded the requirements of the republican breed standard by $150-291.5 \mathrm{~kg}$, the fat content in milk by $0.30-0.36 \%$, which indicates a fairly high level of their productivity potential. Studied in the same cows of the given herd productivity for III and older lactation (Table 4).

Table 4. Dairy productivity of cows III and over lactation obtained from different cattle.

\begin{tabular}{|c|c|c|c|c|}
\hline \multirow{2}{*}{ Index } & \multicolumn{4}{|c|}{ Nick-name of the sire cattle } \\
\cline { 2 - 5 } & Karan & Koster & Emil & Jordan \\
\hline Number of heads & 21 & 40 & 67 & 15 \\
\hline Milk yield, kg & $4,347.8 \pm 167.4$ & $4,419.4 \pm 138.5$ & $4,135.0 \pm 73.2$ & $4,210.4 \pm 51.5$ \\
\hline Fat content in milk, \% & $3.94 \pm 0.012$ & $3.93 \pm 0.01$ & $3.96 \pm .0 .03$ & $3.98 \pm 0.03$ \\
\hline Milk fat yield, kg & $171.3 \pm 6.4$ & $173.7 \pm 5.9$ & $163.7 \pm 3.3$ & $167.6 \pm 6.5$ \\
\hline Milk yield of 4\% milk, kg & $4,282.6 \pm 170.2$ & $4,342.0 \pm 141.2$ & $4,093.6 \pm 78.5$ & $4,189.3 \pm 61.7$ \\
\hline Milk ratio, kg & $882.8 \pm 10.7$ & $892.6 \pm 11.1$ & $828.3 \pm 9.7$ & $848.0 \pm 9.9$ \\
\hline Biomass, kg & $492.5 \pm 5.3$ & $495.1 \pm 6.3$ & $499.2 \pm 5.9$ & $496.5 \pm 5.9$ \\
\hline
\end{tabular}

As can be seen from the data in Table 4, full-aged cows of the calf of a cattle -producer Koster, in which milk yield, respectively, by 71.6 are distinguished by a higher milk productivity; 284.4 and $209.0 \mathrm{~kg}$, milk fat yield by $2.4 ; 10.0$ and $7.1 \mathrm{~kg}$, milk yield of $4 \%$ milk by $59.4 ; 284.4$ and $152.7 \mathrm{~kg}$, milk production coefficient by $9.8 ; 64.3$ and $44.6 \mathrm{~kg}$ exceed the corresponding indicators of the calves of Karan, Emil and Jordan. The calves of all these cattle were distinguished by their high milk production potential. The calves of the cattle Karan, Koster, Emil and Jordan had milk yield at 1174.8, respectively; 1219.4; 935.0 and $1010.4 \mathrm{~kg}$, milk fat yield by $52.9 ; 55.3 ; 45.3$ and $49.9 \mathrm{~kg}$ are higher than the requirements of the Swiss breed standard, the milk production coefficient confirmed the pronounced milk type of the calves of all cattle. Similar studies were carried out in the breeding herd of the farm named after T. Shokirova, Asaka district, Andijan province (Table 5). 
Table 5. Dairy productivity of cows-first heats obtained from different cattle.

\begin{tabular}{|c|c|c|c|c|}
\hline \multirow{2}{*}{ Index } & \multicolumn{4}{|c|}{ Nick-name of the sire cattle } \\
\cline { 2 - 5 } & Peter & Roksi & Demon & Corona \\
\hline Number of heads & 15 & 15 & 9 & 6 \\
\hline Milk yield, kg & $3,378.2 \pm 70.3$ & $3,394.0 \pm 69.8$ & $3,675.9 \pm 81.0$ & $3,712.5 \pm 85.3$ \\
\hline Fat content in milk, \% & $4.00 \pm 0.03$ & $4.10 \pm 0.03$ & $4.06 \pm 0.04$ & $4.12 \pm 0.04$ \\
\hline Milk fat yield, kg & $135.1 \pm 6.3$ & $139.1 \pm 5.5$ & $149.2 \pm 6.8$ & $152.9 \pm 7.0$ \\
\hline $\begin{array}{c}\text { Milk yield of 4\% } \\
\text { milk, kg }\end{array}$ & $3,378.2 \pm 64.5$ & $3,478.8 \pm 72.5$ & $3,731.0 \pm 77.2$ & $3,823.9 \pm 80.5$ \\
\hline Milk ratio, $\mathrm{kg}$ & $772.7 \pm 8.1$ & $751.4 \pm 7.0$ & $833.8 \pm 6.2$ & $850.7 \pm 8.0$ \\
\hline Biomass, kg & $437.2 \pm 3.6$ & $451.7 \pm 4.2$ & $441.0 \pm 2.5$ & $436.4 \pm 4.1$ \\
\hline
\end{tabular}

The analysis of the data obtained showed that the calves of the studied cattle -producers for the 1st lactation are characterized by a rather high milk productivity and fat-milk content, the milk yield of which is $978.2(40.76 \%)-1312.5 \mathrm{~kg}(54.69 \%)$, the yield of milk fat is $46.3-64.1 \mathrm{~kg}(52.14-72.18 \%)$ exceeds the requirements of the breed standard. In terms of milk yield, the calves of cattle Korona surpass the calves of other cattle by $36.6-334.3 \mathrm{~kg}$ of milk, and their milk yield per $100 \mathrm{~kg}$ of biomass was $17.2-99.3 \mathrm{~kg}$ ( $\mathrm{P}>0.999)$ higher than that of their calves other cattle. We continued to study the productive qualities of these cows for III and older lactation (Table 6 and Fig. 1).

Table 6. Dairy productivity and living mass of calves of cattle of different genotypes for III and over lactation.

\begin{tabular}{|c|c|c|c|c|}
\hline \multirow{2}{*}{ Index } & \multicolumn{4}{|c|}{ Nick-name of the sire cattle } \\
\cline { 2 - 5 } & Peter & Roksi & Demon & Corona \\
\hline Number of heads & 15 & 15 & 9 & 6 \\
\hline Milk yield, kg & $4,197.7 \pm 22.5$ & $4,205 \pm 22.3$ & $4,711.9 \pm 42.5$ & $4,698.7 \pm 47.7$ \\
\hline Fat content in milk,\% & $4.01 \pm 0.03$ & $4.13 \pm 0.03$ & $4.12 \pm 0.06$ & $4.15 \pm 0.05$ \\
\hline Milk fat yield, kg & $172.11 \pm 7.9$ & $173.7 \pm 6.4$ & $194.1 \pm 8.1$ & $195.0 \pm 5.3$ \\
\hline $\begin{array}{c}\text { Milk yield of 4\% } \\
\text { milk, kg }\end{array}$ & $4,302.6 \pm 73.7$ & $4,341.7 \pm 61.4$ & $4,853.2 \pm 60.2$ & $4,874.9 \pm 84.2$ \\
\hline Milk ratio, kg & $840.4 \pm 9.0$ & $803.4 \pm 7.3$ & $917.1 \pm 7.3$ & $910.6 \pm 7.6$ \\
\hline Biomass, kg & $499.5 \pm 3.30$ & $523.4 \pm 3.16$ & $513.8 \pm 1.35$ & $516.0 \pm 2.88$ \\
\hline
\end{tabular}

The data in the table indicate that the milk yield of the full-aged calves of the calf Demon is 514, respectively; 506.9 and $13.2 \mathrm{~kg}$ higher (Figure 1) than the calves of the cattle Peter, Roksi, Corona, milk fat yield by $22.0 ; 20.4 \mathrm{~kg}$, milk yield of $4 \%$ milk by 550.6 and $511.5 \mathrm{~kg}$, milk production coefficient by 76.7 and $113.7 \mathrm{~kg}$ higher than that of the calves of cattle Peter and Roksi.

The milk yield of the calves of the cattle Peter, Roksi and Corona of Austrian selection was $997.7-1005.0 \mathrm{~kg}(31.18-46.83 \%)$, the yield of milk fat is $53.7-55.3 \mathrm{~kg}$ higher than that of the calves of the Demon calf and the milk yield of the calves of these cattle exceeds the requirements of the Swiss breed standard by $979-1511 \mathrm{~kg}$, or $31.18-47.25 \%$. 


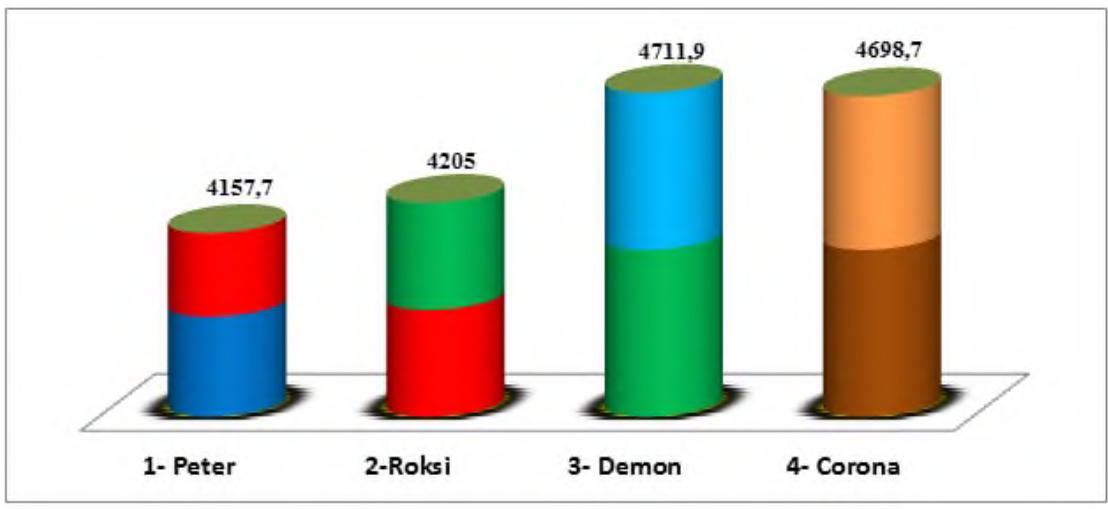

Fig. 1. Change in milk yield of full-age calves of different cattle, $\mathrm{kg}$.

In the breeding herd "Shamshir Al Akbar" of the Shakhrisabz district of the Kashkadarya province, we studied the milk productivity of local selection Swiss cows obtained from 5 purebred sire cattle of this breed (Table 7).

As the data in Table 7 show, the calves of cattle -producers of the Swiss breed of local selection have almost the same level of milk yield, and the calves of the calf German have similar productivity indicators. The milk yield of calves of the cattle -producer of the Dnepr was 49.4-185.6 kg (1.27-4.9\%), the yield of milk fat was 4.7-11.4 kg (3.0-7.6\%), milk yield of $4 \%$ milk by $118.6-403.2 \mathrm{~kg}(3.0-11.1 \%)$, milk production ratio by $29.0-51.9 \mathrm{~kg}(4.1-$ $7.7 \%$ ) higher than from the calves of the cattle Sputnik, German, Qoplon and Elbrus.

Fig. 2 shows the proportion of milk yield of calves of different producers, from which it can be seen that the proportion of milk yield of calves of Dnepr and Elbrus in the ratio of milk yield of calves of other cattle has almost the same level and is slightly higher than the milk yield of calves of other cattle.

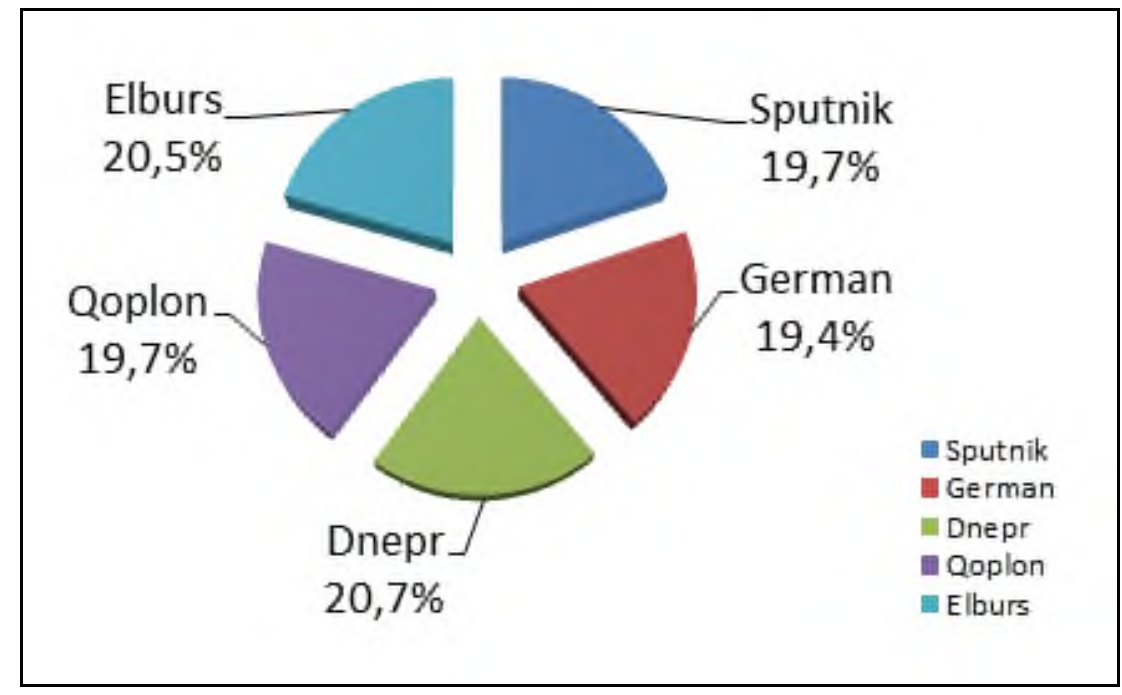

Fig. 2. Share of milk yield of cows of various Swiss cattle, $\%$.

Analysis of the data allows us to summarize that the use of the semen of cattle producers of the Swiss breed, regardless of origin, has a positive effect on the improvement of the main breeding characteristics of cows of the Swiss breed of Uzbekistan. The results obtained indicate that the use of cattle from leading countries in the mating of Swiss cattle 
of the republic makes it possible to improve the genetic potential of the resulting offspring and create new breeding achievements in the qualitative transformation of Swiss cattle.

Table 7. Dairy productivity of calves of different cattle - Manufacturers for III and over lactation.

\begin{tabular}{|c|c|c|c|c|c|c|c|c|c|c|}
\hline \multirow[b]{3}{*}{ Index } & \multicolumn{10}{|c|}{ Nick-name of the sire cattle } \\
\hline & \multicolumn{2}{|c|}{ Sputnik } & \multicolumn{2}{|c|}{ German } & \multicolumn{2}{|c|}{ Dnepr } & \multicolumn{2}{|c|}{ Qoplon } & \multicolumn{2}{|l|}{ Elbrus } \\
\hline & $\bar{X} \pm S \bar{x}$ & 8 & $\bar{X} \pm S \bar{x}$ & $\begin{array}{l}\dot{0} \\
\dot{0}\end{array}$ & $\bar{X} \pm S \bar{x}$ & $\begin{array}{l}0 \\
\dot{0}\end{array}$ & $\bar{X} \pm S \bar{x}$ & $\begin{array}{l}\dot{0} \\
\dot{0}\end{array}$ & $\bar{X} \pm S \bar{x}$ & है \\
\hline $\begin{array}{l}\text { Number } \\
\text { of heads }\end{array}$ & \multicolumn{2}{|c|}{12} & \multicolumn{2}{|l|}{14} & \multicolumn{2}{|l|}{4} & \multicolumn{2}{|l|}{4} & \multicolumn{2}{|l|}{3} \\
\hline 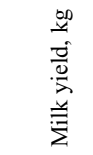 & 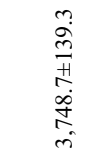 & $\stackrel{m}{\mathrm{I}}$ & 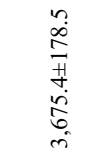 & $\stackrel{n}{=}$ & $\begin{array}{l}\vec{t} \\
\dot{b} \\
\dot{H} \\
m \\
m \\
\tilde{m} \\
\dot{m}\end{array}$ & $\stackrel{\infty}{\sim}$ & 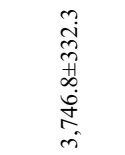 & $\stackrel{+}{\ddot{n}}$ & 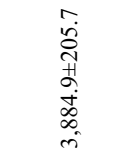 & 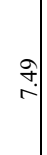 \\
\hline 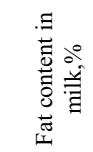 & $\begin{array}{l}\text { o. } \\
\dot{0} \\
0 \\
\dot{0} \\
\dot{+}\end{array}$ & $\underset{\infty}{\infty}$ & 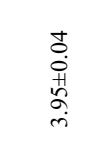 & $\stackrel{q}{i}$ & 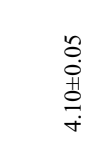 & $\stackrel{\sigma}{\sigma}$ & 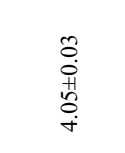 & $\stackrel{\mathcal{f}}{-}$ & 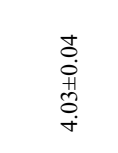 & $\stackrel{f}{-}$ \\
\hline 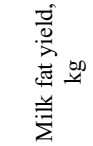 & $\begin{array}{l}\hat{\sigma} \\
\dot{+} \\
+ \\
\partial \\
\partial \\
\dot{g}\end{array}$ & $\stackrel{+}{\circ}$ & 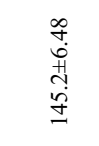 & $\bar{\sigma}$ & $\begin{array}{l}\hat{\imath} \\
\text { in } \\
m \\
\underline{0} \\
\underline{0}\end{array}$ & तु & $\begin{array}{l}\stackrel{+}{\mathrm{I}} \\
\underset{\mathrm{H}}{\mathrm{i}}\end{array}$ & $\stackrel{\text { I }}{ \pm}$ & 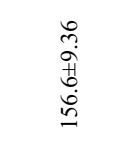 & $\begin{array}{l}n \\
\infty \\
\infty\end{array}$ \\
\hline 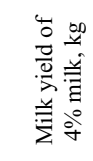 & 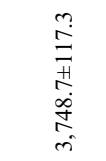 & $\stackrel{+}{\ominus}$ & $\begin{array}{l}\overrightarrow{\mathrm{i}} \\
\overrightarrow{\mathrm{H}} \\
\vec{\forall} \\
\text { ते } \\
\text { i }\end{array}$ & $\stackrel{\square}{\sigma}$ & 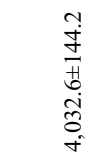 & ָึู & 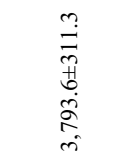 & $\stackrel{\mathcal{I}}{\Xi}$ & 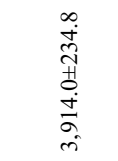 & f. \\
\hline 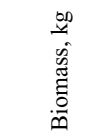 & 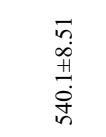 & กิ & $\begin{array}{l}n \\
n \\
i n \\
\# \\
\dot{m} \\
\dot{n}\end{array}$ & $\stackrel{\bar{\infty}}{\dot{m}}$ & 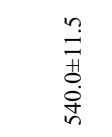 & $\stackrel{R}{i}$ & $\begin{array}{l}m \\
m \\
m \\
n \\
m \\
m \\
m\end{array}$ & $\underset{\stackrel{J}{f}}{\stackrel{f}{*}}$ & $\begin{array}{l}\text { ㄱ. } \\
0 \\
0 \\
0 \\
i \\
i n \\
i n\end{array}$ & ?ִ \\
\hline 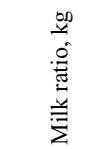 & 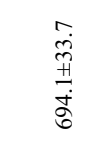 & $\stackrel{0}{\dot{\theta}}$ & 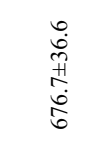 & $\ddot{\ddot{n}}$ & 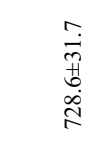 & $\stackrel{\stackrel{n}{n}}{\stackrel{n}{n}}$ & 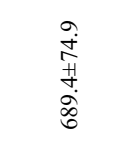 & $\stackrel{-\infty}{\infty}$ & $\begin{array}{l}\hat{i} \\
\text { ते } \\
\text { oे }\end{array}$ & $\overrightarrow{0}$. \\
\hline
\end{tabular}

\section{Conclusions}

1. The level of milk production of Swiss cows is closely related to the genotype of the fathers. Cattle used in breeding herds for selection, regardless of origin, are characterized by a high genetic potential for productivity. Cattle of Austrian selection are characterized by a particularly high potential for productivity. 
2. In the full-age calves of the cattle -producer Zhuri in the Avaz breeding herd, milk yield by $191.3-417.1 \mathrm{~kg}$, milk yield of $4 \%$ milk by $212.6-472.6 \mathrm{~kg}$, milk production coefficient by $26.1-45.8 \mathrm{~kg}$ surpasses the corresponding figures of the calves of other cattle.

3. In the breeding herd "Savay-naslchilik chorvachilik", the calves of all cattle have a high potential for milk production. The calves of the cattle Karan, Koster, Emil and Jordan had milk yield at 1174.8 , respectively; $1219.4 ; 935.0$ and $1010.4 \mathrm{~kg}$, milk fat yield by 52.9 ; $55.3 ; 45.3$ and $49.9 \mathrm{~kg}$ are higher than the requirements of the republican standard of the Swiss breed, the milk production coefficient confirmed the pronounced milk type of the calves of all cattle.

4. Similar data were obtained in other experimental herds, the cows of which, regardless of origin, are characterized by a sufficiently high milk productivity, which indicates the high breeding value of Swiss cattle.

\section{References}

1. M. I. Ashirov, Y. Nasirdinov, B. Ashirov, N. Ruziboev, J. Zooveterinary, 7, 26-28 (2015)

2. Y. Nasirdinov, Materials of the IV-th International Conference, FGBNU, Russia, 2, 8485 (2017)

3. F. B. Bahriddinov, M. I. Ashirov, B. M. Ashirov, Y. Nasirdinov, Proceedings of the International Conference - Solenoe Zaymishche, Astrakhan, Russia, 564-567 (2019)

4. F. B. Bahriddinov, M. I. Ashirov, Y. N. Nasirdinov, B. M. Ashirov, J. Dairy and beef cattle breeding, 4, 19-22 (2019)

5. A. S. Any, A. S. Gryaznov, J. Zootechnia, 8, 1-12 (1989)

6. A. Dankvert, T. Japaridze, J. Dairy and beef cattle breeding, 2, 2-5 (2010)

7. V. I. Dmitrieva, D. N. Koltsov, M. E. Gontov, V. K. Chernushenko, J. Zootechnics, 4, 18-20 (2019)

8. I. Dunin, A. Kochetkov, V. Sharkaev, J. Dairy and beef cattle breeding, 6, $2-5$ (2010)

9. V. I. Listratenkova, V. K. Chernushenko, N. S. Petkevich, D. N. Koltsov, J. Zootechnia, 7, 4-6 (2009)

10. J. Loginov, J. Dairy and beef cattle breeding, 4, 1-14 (2004)

11. M. I. Ashirov, B. M. Ashirov, F. B. Bakhriddinov, International Journal of Science and Research, 14, 123-141 (2017)

12. U. R. Soatov, M. I. Ashirov, An International Multidisciplinary Research Journal, 8, 104-117 (2020) 